\title{
Description, systematics and ecology of a new tanaidacean (Crustacea, Peracarida) species from mediterranean fish farms
}

\author{
P. Esquete ${ }^{1 *}$ (D) and V. Fernandez-Gonzalez ${ }^{2}$
}

\begin{abstract}
An undescribed species of tanaidacean belonging to the genus Hexapleomera, tribe Pancolini, Hexapleomera bultidactyla sp. nov. was found in fouling community samples from off-coast fish farms cages in the western Mediterranean Sea. The species can be distinguished from other Hexapleomera species by the presence of a ventral apophysis on the dactylus of the chela in males. Other diagnostic characters (in combination) include a male antennule with five aesthetascs, the female with three, the maxillule palp with four terminal setae and maxilliped basis and coxa each with two setae; the male fixed finger with four ventral setae and proximal apophysis, the female chela fixed finger with a proximal triangular apophysis, an apophysis on the coxa of pereopod 1, a pleopod 3 basis with three outer setae, and an uropod of four segments. Although several substrata were investigated, the species was most abundant where the turf formed by Ceramiaceae algae and the hydroid Aglaophenia sp. was dominant. An updated identification key to all the species of Hexapleomera is provided.
\end{abstract}

Keywords: Hexapleomera, Mediterranean, Aquaculture facilities, Fouling, Fecundity

\section{Background}

Tanaidaceans (Order Tanaidacea Dana, 1846) are a group of peracarid crustaceans that are frequently found in very high densities, accounting for a significant proportion of the benthic community. They are considered to have a sedentary lifestyle, with limited displacement capacity and no obligate dispersive phase in their life history, which leads to allopatric speciation, niche specificity and high frequency of endemic species [1].

The genus Hexapleomera Dudich, 1931 was described in order to accommodate the species Hexapleomera robusta (Moore, 1984) [2], previously included in the genus Tanais Latreille, 1831. The validity of the genus was subject of discussion, until Sieg [3] delimited the generic characters. Hexapleomera was long considered monotypic, and the type species $H$. robusta cosmopolitan [2]. Bamber [4] revised material from various collections

\footnotetext{
*Correspondence: pesquete@ua.pt

1 Departamento de Biologia and CESAM, Universidade de Aveiro, Aveiro, Portugal

Full list of author information is available at the end of the article
}

recognizing five species that are geographically well differentiated, with the exception of the type species that is found in the Mediterranean, Northwest Atlantic, "possibly the Caribbean", and Atlantic Brazil [4]. In the same paper, Bamber included a comparison of the most relevant morphological characters for all the species of the genus (opus cit., Table 1), and considered that the redescription and illustrations of $H$. robusta by Sieg [3] as valid for the species. We agree with his conclusions, hence, will refer to the redescription when $H$. robusta is mentioned throughout the present paper.

Species of Hexapleomera have been found on a variety of substrates including (but not limited to) sea turtles, manatees, and also yatch hull fouling [ 4 and references therein]. There are two valid species cited for the Mediterranean Sea: Hexapleomera statella Bamber, 2012, found living amongst algae, polychaetes and sand, and $H$. robusta, recovered from the carapace of sea turtles (see [4]); Hexapleomera crassa (Riggio, 1975) nomen nudum was collected in Sicily and Naples.

During a study of the epifauna associated with fish farm fouling carried out from May to October 2010, 
Table 1 Quantitative samples in fish farms off Alicante (Spain) where species of Hexapleomera were present

\begin{tabular}{|c|c|c|c|c|c|c|c|c|c|}
\hline \multirow[t]{2}{*}{ Sample } & \multicolumn{2}{|c|}{ Coordinates } & \multirow[t]{2}{*}{ Substrate (dominant species) } & \multicolumn{5}{|c|}{ H. bultidactyla } & \multirow[t]{2}{*}{ H. robusta } \\
\hline & w & $\mathbf{N}$ & & Prep. fem. & Cop. fem. & Males & Juv. & Total & \\
\hline CTa1VII & $0^{\circ} 36.06^{\prime}$ & $38^{\circ} 5.32^{\prime}$ & Ceramiaceae & 182 & 13 & 19 & 76 & 290 & \\
\hline CTa2VII & $0^{\circ} 36.06^{\prime}$ & $38^{\circ} 5.32^{\prime}$ & Ceramiaceae & 126 & 9 & 12 & 27 & 174 & \\
\hline CTh1VII & $0^{\circ} 36.06^{\prime}$ & $38^{\circ} 5.32^{\prime}$ & P. disticha & 11 & 1 & & 1 & 13 & \\
\hline CTh2VII & $0^{\circ} 36.06^{\prime}$ & $38^{\circ} 5.32^{\prime}$ & P. disticha & 22 & 2 & & & 24 & Present $^{a}$ \\
\hline CTh3VII & $0^{\circ} 36.06^{\prime}$ & $38^{\circ} 5.32^{\prime}$ & P. disticha & 16 & 3 & 2 & & 21 & \\
\hline CTm1VII & $0^{\circ} 36.06^{\prime}$ & $38^{\circ} 5.32^{\prime}$ & M. galloprovincialis & 1 & & & & 1 & \\
\hline CTm2VII & $0^{\circ} 36.06^{\prime}$ & $38^{\circ} 5.32^{\prime}$ & M. galloprovincialis & 7 & 3 & 1 & & 11 & \\
\hline CTm3VII & $0^{\circ} 36.06^{\prime}$ & $38^{\circ} 5.32^{\prime}$ & M. galloprovincialis & 10 & 7 & 3 & 1 & 21 & \\
\hline CMa1VII & $0^{\circ} 36.02$ & $38^{\circ} 5.24^{\prime}$ & Ceramiaceae & 3 & & 3 & & 6 & \\
\hline CMa2VII & $0^{\circ} 36.02$ & $38^{\circ} 5.24^{\prime}$ & Ceramiaceae & 110 & 27 & 32 & 47 & 216 & \\
\hline CMa3VIII & $0^{\circ} 36.02$ & $38^{\circ} 5.24^{\prime}$ & Ceramiaceae & 0 & & & & 0 & Present $^{\mathrm{a}}$ \\
\hline CMh2VII & $0^{\circ} 36.02$ & $38^{\circ} 5.24^{\prime}$ & P. disticha & 1 & & & & 1 & \\
\hline CMh3VII & $0^{\circ} 36.02$ & $38^{\circ} 5.24^{\prime}$ & P. disticha & 1 & & & & 1 & \\
\hline $\mathrm{CMm} 2 \mathrm{VII}$ & $0^{\circ} 36.02$ & $38^{\circ} 5.24^{\prime}$ & M. galloprovincialis & & 1 & & & 1 & \\
\hline CMm3VII & $0^{\circ} 36.02$ & $38^{\circ} 5.24^{\prime}$ & M. galloprovincialis & 5 & & & & 5 & \\
\hline Total & & & & 495 & 66 & 72 & 152 & 785 & \\
\hline
\end{tabular}

Prep. fem. preparatory females, cop. females copulatory females, juv. juveniles

a Unpublished data

specimens belonging to an undescribed species of Hexapleomera were collected at several localities of the Mediterranean Sea. In this paper, the species is described and abundance, population structure and fecundity data are provided.

\section{Methods}

The above-mentioned study aimed to determine population densities of peracarids associated to the three main macrohabitats found on aquaculture fouling: mussels, hydroids and algae. For this, two fish farms, located off the coast of Guardamar del Segura (Alicante, SE Spain: $\left.38^{\circ} 5^{\prime} 45.88^{\prime \prime} \mathrm{N} ; 0^{\circ} 36^{\prime} 15.84^{\prime \prime} \mathrm{W}\right)$, were sampled quantitatively in July 2010 (see Fig. 1; Table 1). Each farm consisted of 18 rings with a diameter of $19 \mathrm{~m}$ or $25 \mathrm{~m}$ and cage nets reaching depths from 12 to $15 \mathrm{~m}$. The cage structures are located 3-4 km off-coast and grow European sea bass Dicentrarchus labrax (Linnaeus, 1758) and gilthead sea bream Sparus aurata Linnaeus, 1758. Fouling communities at the two studied fish farms were sampled by scraping fouling organisms from mooring ropes, between 3 and $12 \mathrm{~m}$ depth. From each farm, nine replicates of $20 \mathrm{~cm}$ in length per rope were cleared using an air-lift device to ensure a quantitative method in high hydrodynamic conditions. The diameter of each rope was recorded to calculate an accurate sampled surface. The samples were sieved through a $250 \mu \mathrm{m}$ mesh with seawater in order to retain small peracarid specimens and juvenile organisms and subsequently preserved in $4 \%$ formalin seawater solution. In the laboratory, all macrofaunal specimens were sorted and preserved in $70 \%$ ethanol and all sessile organisms were identified, if possible to species level, and dried at $105^{\circ} \mathrm{C}$ during $24 \mathrm{~h}$.

During the identification work, the undescribed species of tanaid belonging to the genus Hexapleomera described below was found. Morphological terminology follows that of Bamber and Sheader [7]; serially repetitive body parts, such as the subdivisions of the antennal flagella and those of the uropodal rami are segments, while those with independent musculature, such as the parts of the pereopods are articles. Measurements were made axially, dorsally on the body and antennae, and laterally on other appendages. Type-material is lodged at the Museo Nacional de Ciencias Naturales, Madrid (MNCN). Preparatory females are those with oostegites. Copulatory females are those with complete marsupia. Individuals with no secondary sexual characters differentiated are considered juveniles.

Specimens of the Hexaplomera were sorted according to sex and life-history stage: males, females, brooding females (including eggs per female) and juveniles, and then counted for calculation of population densities. Fecundity was defined as number of embryos or mancae per copulatory female (excluding those with damaged marsupia because part of the offspring were potentially lost), and calculated from the sum of all eggs in the 


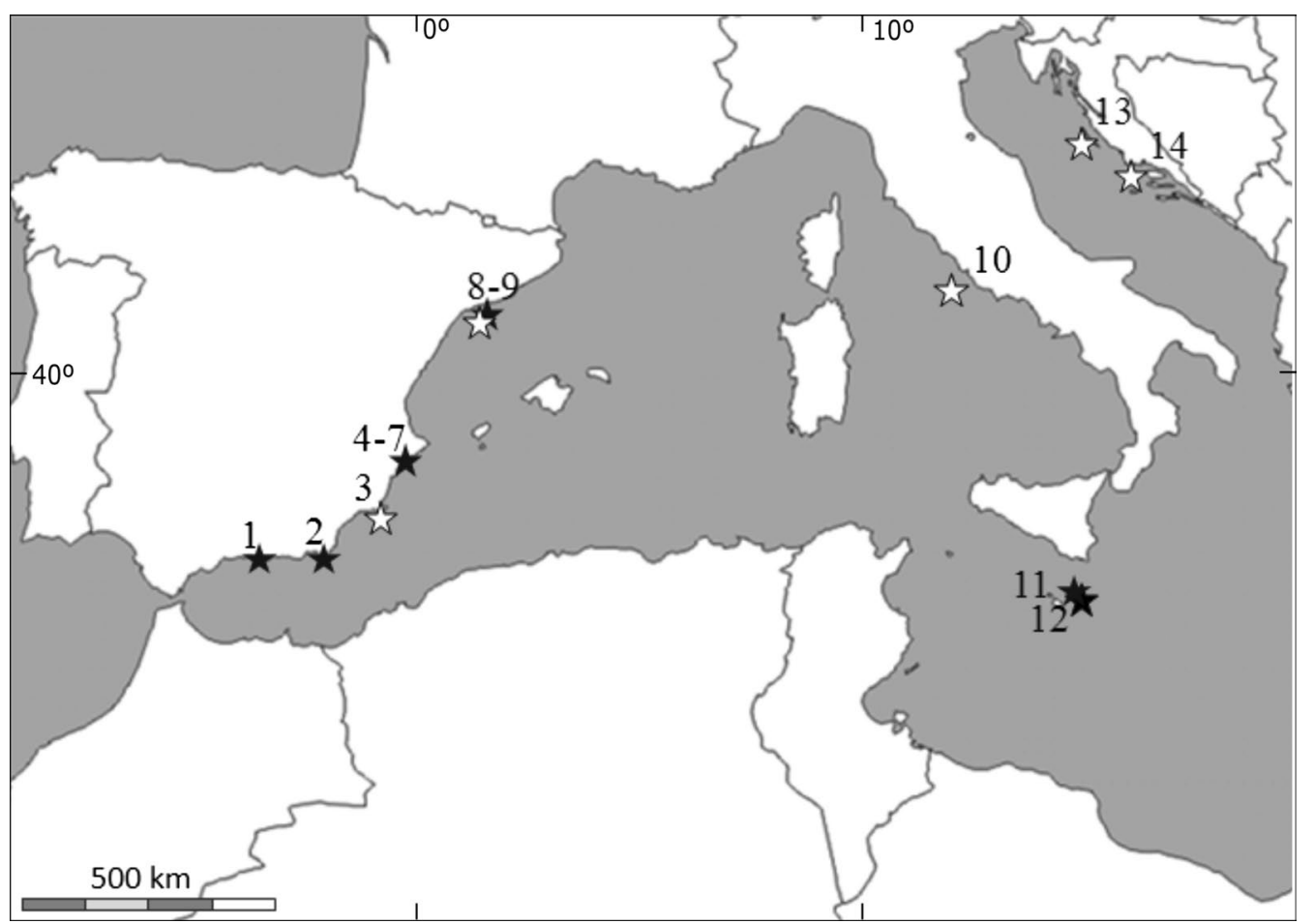

Fig. 1 Map of the Mediterranean Sea showing sampling locations (white star symbols: 1 Málaga, Spain; 2 Almería, Spain, 3 Murcia, Spain; 4-7 Alicante, Spain, 8-9 Tarragona, Spain, 10 Follonica, Italy, 11 Qawra, Malta, 12 Delimara, Malta, 13 Ugljan Island, Croatia and 14 Brac Island, Croatia) and confirmed records of Hexapleomera bultidactyla at off-coast aquaculture facilities (black stars). 4-5 quantitative sampling

marsupium of each female and then the division by the number of copulatory females $[5,6]$. Females with only one marsupium were included for consistency. Densities were standardized to the total amount of habitat per sample, calculated as the dry weight of all sessile organisms and presented as individuals $\mathrm{m}^{-2}$ and individuals $100 \mathrm{~g}^{-1}$ dry weight.

Additionally, samples of a previous qualitative study of epifauna associated to aquaculture facilities in the Mediterranean Sea were examined in order to determine the presence/absence of the new species along de Mediterranean coast. The mentioned study included a total of fourteen aquaculture facilities located off the coasts of Spain (9), Italy (1), Croatia (2) and Malta (2) (see Fig. 1; Table 2). Eight of these fish farms were dedicated to $S$. aurata and D. labrax farming (1 Málaga, Spain; 1 Almería, Spain, 1 Murcia, Spain, 2 Alicante, Spain, 2 Tarragona, Spain and 1 Follonica, Italy); four fish farms stocked with young Atlantic bluefin tuna Thunnus thynnus (Linnaeus, 1758) from the wild (Qawra, Malta; Il-Hofriet, Malta; Brac, Croatia and Ugjlan, Croatia); one was a shellfish longline stocked with Ostrea edulis Linnaeus, 1758 (Alicante, Spain); and one was an inactive fish farm, which retains all the structures except the net-pens and had not been used for production for the previous two years (Alicante, Spain).

\section{Results \\ Systematics}

Order Tanaidacea Dana, 1849

Suborder Tanaidomorpha Sieg 1980

Superfamily Tanaidoidea Nobili, 1906

Family Tanaididae Nobili, 1906

Subfamily Pancolinae Sieg, 1980

Tribe Pancolini Sieg, 1980

Genus Hexapleomera Dudich, 1931

Hexapleomera bultidactyla sp. nov. (Figures 2, 3, 4, 5)

Material examined. Holotype: ovigerous female MNCN 20.04/10595, $3.0 \mathrm{~mm}$ length, St. CMa2VII, $38^{\circ} 5.24^{\prime} \mathrm{N} \quad 0^{\circ} 36.02^{\prime} \mathrm{W}$, off Alicante, Ceramiaceae, 3-12 m depth, 14 July 2010. Male Allotype: MNCN 20.04/10596, $3.2 \mathrm{~mm}$ length, St. CMa2VII, 38 $5.24^{\prime} \mathrm{N}$ $0^{\circ} 36.02^{\prime} \mathrm{W}$, off Alicante, Ceramiaceae, 3-12 m depth, 14 July 2010. Other paratypes: Ovigerous female MNCN 20.04/10597, female MNCN 20.04/10598, male MNCN 20.04/10599, juvenile MNCN 20.04/10600, St. CMa2VII, $38^{\circ} 5.24^{\prime} \mathrm{N} 0^{\circ} 36.02^{\prime} \mathrm{W}$, off Alicante, Ceramiaceae, 3-12 m depth, 10 May 2010. All coll. V. 
Table 2 Qualitative samples in fish farms in the Mediterranean where species of Hexapleomera were present

\begin{tabular}{|c|c|c|c|c|c|c|c|}
\hline \multirow[t]{2}{*}{ Country } & \multirow[t]{2}{*}{ Location } & \multirow[t]{2}{*}{ Sample } & \multicolumn{2}{|c|}{ Coordinates } & \multirow[t]{2}{*}{ Substrate (dominant species) } & \multirow[t]{2}{*}{ H. bultidactyla } & \multirow[t]{2}{*}{ H. robusta } \\
\hline & & & Lon. & Lat. & & & \\
\hline Spain & Guardamar del Segura & MT & $0^{\circ} 36.02^{\prime} \mathrm{W}$ & $38^{\circ} 6.01^{\prime} \mathrm{N}$ & Gelidium crinale & 71 & \\
\hline Spain & Santa Pola & OST & $0^{\circ} 32.12^{\prime} \mathrm{W}$ & $38^{\circ} 9.03^{\prime} \mathrm{N}$ & Ceramiaceae & 87 & Present $^{a}$ \\
\hline Spain & Málaga & MMCS-2 & $4^{\circ} 21.51^{\prime} \mathrm{W}$ & $36^{\circ} 42.32^{\prime} \mathrm{N}$ & M. galloprovincialis & 16 & \\
\hline Spain & Almería & AMBS-1 & $2^{\circ} 32.27^{\prime} \mathrm{W}$ & $36^{\circ} 48.85^{\prime} \mathrm{N}$ & M. galloprovincialis & 12 & \\
\hline Spain & Tarragona & CR1 & $0^{\circ} 35.28^{\prime} \mathrm{E}$ & $40^{\circ} 31.86^{\prime} \mathrm{N}$ & Obelia sp. & 27 & \\
\hline Malta & Qawra & MaltA & $14^{\circ} 41.5^{\prime} \mathrm{E}$ & $35^{\circ} 97.1^{\prime} \mathrm{N}$ & - & 29 & \\
\hline Malta & il-Hofriet & MaltB & $14^{\circ} 56.4^{\prime} \mathrm{E}$ & $35^{\circ} 83.98^{\prime} \mathrm{N}$ & - & 10 & \\
\hline Croatia & Brac & Brac2 & $16^{\circ} 27.60^{\prime} \mathrm{E}$ & $43^{\circ} 17.73^{\prime} \mathrm{N}$ & Cladophorasp. & 0 & Present $^{\mathrm{a}}$ \\
\hline
\end{tabular}

Lon. longitude, Lat. latitude

a Unpublished data

Fernandez-Gonzalez, D. Izquierdo-Gomez and P. Sanchez-Jerez.

Other material examined: 195 females, 19 males, 76 juveniles, St. CTa1VII, $38^{\circ} 5.32^{\prime} \mathrm{N} 0^{\circ} 36.06^{\prime} \mathrm{W}$, off Alicante, Ceramiaceae, 3-12 m depth, 13 July 2010. 135 females, 12 males, 27 juveniles, St. CTa2VII, $38^{\circ} 5.32^{\prime} \mathrm{N} 0^{\circ} 36.06^{\prime} \mathrm{W}$, off Alicante, Ceramiacea, 3-12 m depth, 22 July 2010; 12 females, 1 juvenile, St. CTh1VII, $38^{\circ} 5.32^{\prime} \mathrm{N} 0^{\circ} 36.06^{\prime} \mathrm{W}$, off Alicante, Pennaria disticha, 3-12 m depth, 22 July 2010. 24 females, St. CTh2VII, $38^{\circ} 5.32^{\prime} \mathrm{N} 0^{\circ} 36.06^{\prime} \mathrm{W}$, off Alicante, $P$. disticha, 3-12 m depth, 22 July 2010. 19 males, 2 females, St. CTh3VII, $38^{\circ} 5.32^{\prime} \mathrm{N} 0^{\circ} 36.06^{\prime} \mathrm{W}$, off Alicante, $P$. disticha, 3-12 m depth, 22 July 2010. 1 female, St. CTm1VII, $38^{\circ} 5.32^{\prime} \mathrm{N} 0^{\circ} 36.06^{\prime} \mathrm{W}$, off Alicante, Mytilus galloprovincialis, 3-12 m depth, 22 July 2010. 10 females, 1 male, St. CTm2VII, $38^{\circ} 5.32^{\prime} \mathrm{N} 0^{\circ} 36.06^{\prime} \mathrm{W}$, off Alicante, M. galloprovincialis, 3-12 m depth, 22 July 2010. 17 females, 3 males, 1 juvenile, St. CTm3VII, $38^{\circ} 5.32^{\prime} \mathrm{N} 0^{\circ} 36.06^{\prime} \mathrm{W}$, off Alicante, M. galloprovincialis, 3-12 m depth, 22 July 2010. 3 females, 3 males, St. CMa$1 \mathrm{VII}, 38^{\circ} 5.32^{\prime} \mathrm{N} 0^{\circ} 36.06^{\prime} \mathrm{W}$, off Alicante, Ceramiacea, 3-12 m depth, 14 July 2010. 136 females, 31 males, 46 juveniles, St. CMa2VII, $38^{\circ} 5.32^{\prime} \mathrm{N} 0^{\circ} 36.06^{\prime} \mathrm{W}$, off Alicante, Ceramiaceae, 3-12 m depth, 14 July 2010. 1 female, St. CMh2VII, $38^{\circ} 5.32^{\prime} \mathrm{N} 0^{\circ} 36.06^{\prime} \mathrm{W}$, off Alicante, P. disticha, 3-12 m depth, 14 July 2010 2010. 1 female, St. CMh3VII, $38^{\circ} 5.32^{\prime} \mathrm{N} 0^{\circ} 36.06^{\prime} \mathrm{W}$, off Alicante, $P$. disticha, 3-12 m depth, 14 July 2010. 1 female, St. CMm2VII, $38^{\circ} 5.32^{\prime} \mathrm{N}$ $0^{\circ} 36.06^{\prime} \mathrm{W}$, off Alicante, M. galloprovincialis, 3-12 m depth, 14 July 2010. 5 females, St. CMm3VII, $38^{\circ} 5.32^{\prime} \mathrm{N}$ $0^{\circ} 36.06^{\prime} \mathrm{W}$, off Alicante, M. galloprovincialis, 3-12 m depth, 15 July 2010.

Total lengths: Preparatory females $0.9-3.7 \mathrm{~mm}$. Copulatory females: $1.9-3.2 \mathrm{~mm}$. Males: $2.0-3.0 \mathrm{~mm}$. Juveniles: $0.5-1.1 \mathrm{~mm}$.

\section{Diagnosis (adults)}

Male antennule with five aesthetascs, female with three; maxillule palp with four terminal setae; maxilliped basis and coxa each with two setae; male chela dactylus with spinules and proximal apophysis, fixed finger with four setae and proximal apophysis; female chela fixed finger with proximal triangular apophysis; coxa 1 apophysis present; pleopod 3 basis with three outer setae and no inner seta; pleopods 1-3 endopod with one inner seta; uropod of 4 segments.

\section{Description of ovigerous female}

Body (Fig. 2a, b) 3.6 times as long as broad. Cephalothorax subtriangular, as long as broad, eyes with visual elements present, lateral margins with one seta each, and one seta behind each eyelobe. Pereon Pereonite 10.2 times as long as broad, bearing one pair of dorsal and one pair of lateral setae on frontal margin, and one pair of setae on posterolateral margin Pereonite 2.3 times as long as broad, 1.6 times as long as pereonite 1, bearing one pair of dorsal setae and one pair of lateral setae. Pereonite 3 and 40.6 times as long as broad, 1.4 times as long as pereonite 2, bearing one pair of dorsal and two pairs of lateral setae. Pereonite 5 as pereonite $3-4$, but with three pairs of lateral setae. Pereonite 60.4 times as long as broad, 0.6 times as long as pereonite 5 , bearing one pair of sublateral and one pair of posterolateral simple setae. Pleon with pleonite 10.3 times as long as broad, with one pair of dorsal simple setae near frontal margin, and two simple and six plumose setae on each lateral margin. Pleonite 2 with one pair of dorsal simple setae near frontal margin, and two simple and four plumose setae on each lateral margins. Pleonite 3 as pleonite 2. Pleonite 4 about 0.6 times as broad as pleonite 5 , 0.1 times as long as broad, bearing a pair of dorsolateral 

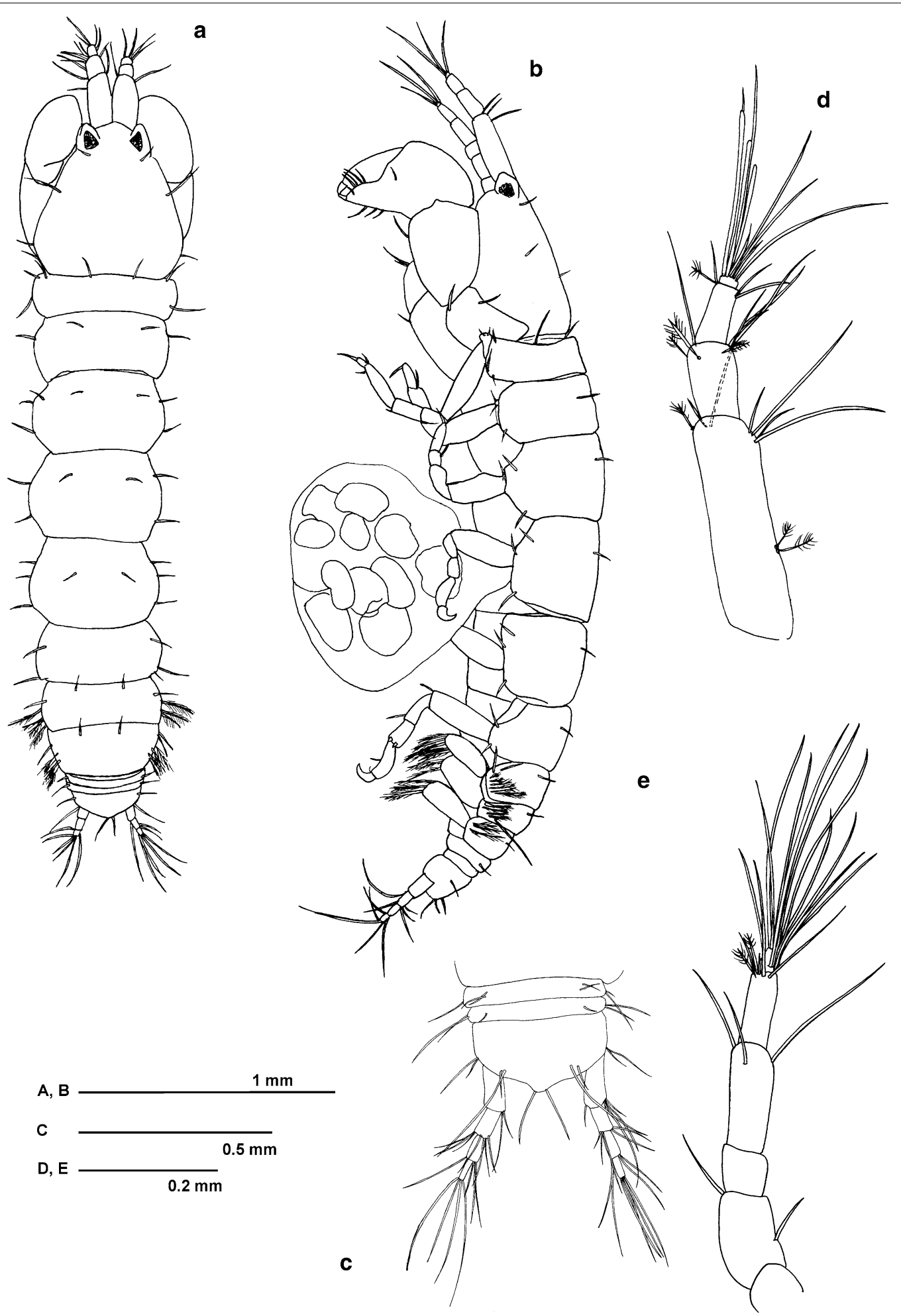

Fig. 2 H. bultidactyla. Female paratype MNCN 20.04/10597: a habitus, dorsal; b habitus, lateral; c pleotelson and uropods. Female paratype MNCN 20.04/10598: d antennule; e antenna 


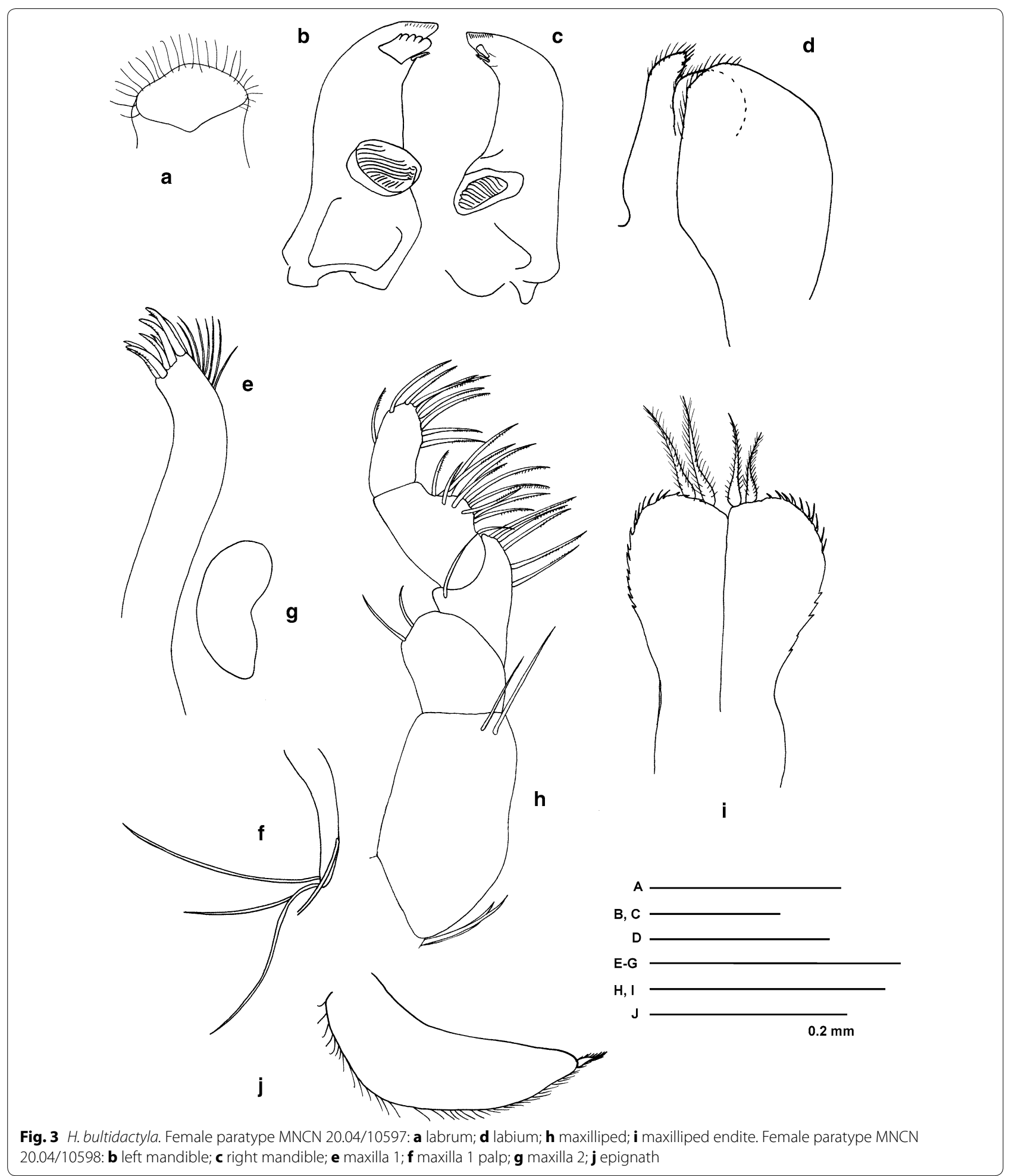

setae and two setae on each lateral margin. Pleonite 5 as pleonite 4, but with one pair of dorsolateral setae instead of two. Pleotelson (Fig. 2c) with two pairs of setae on lateral margins near uropod insertion, two pairs of dorsolateral setae near distal margin, and one pair of apical setae. 

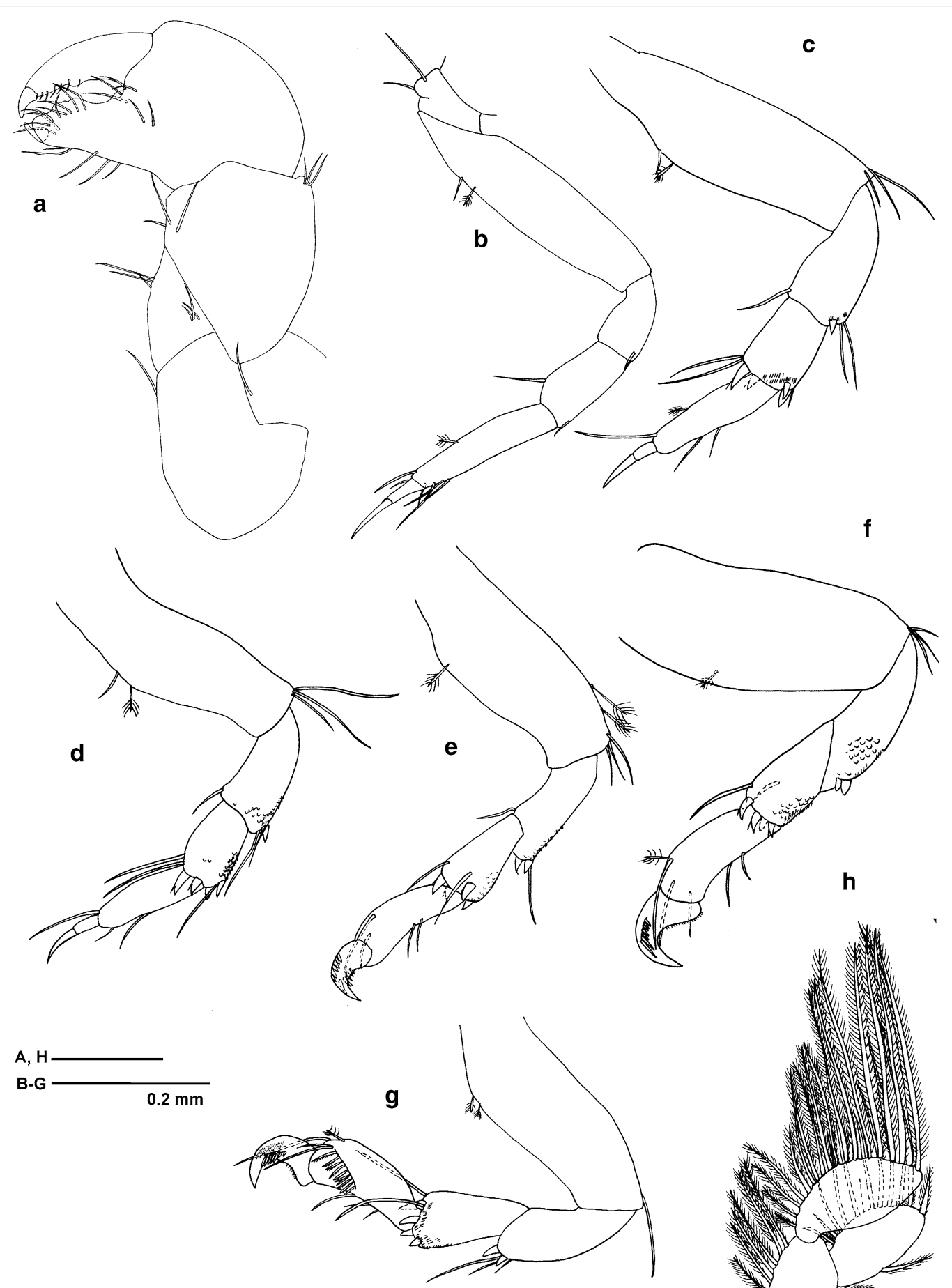

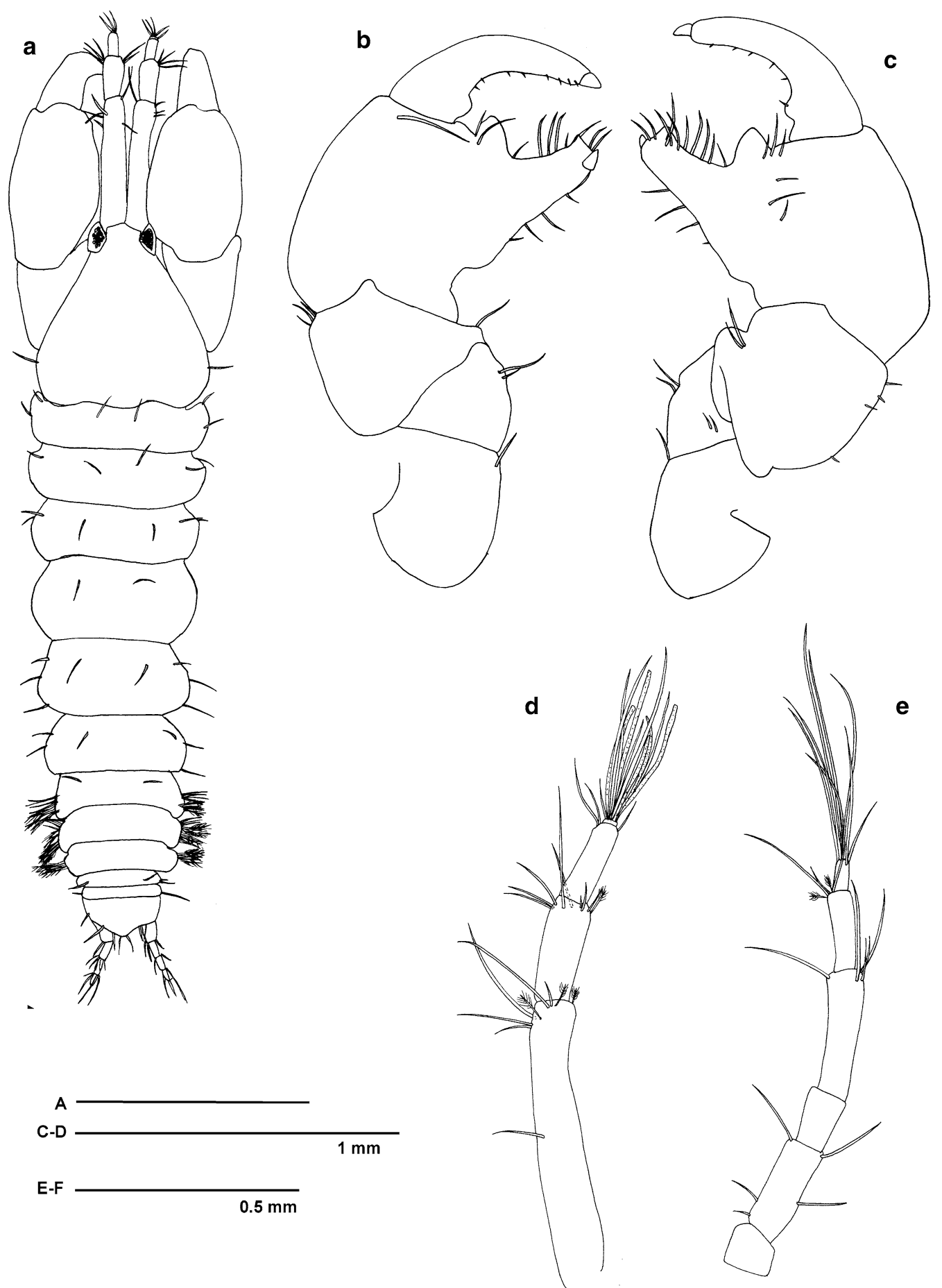

Fig. 5 H. bultidactyla. Male paratype MNCN 20.04/10596: a Habitus. b Cheliped, outer view. c Cheliped, inner view. d Antennule. e Antenna

one simple setae. Article 31.9 times as long as broad, 0.8 times as long as article 2, ventrodistal corner with two simple setae, dorsodistal corner with one simple and one penicillate setae. Article 4 cap-like, 0.5 times as long as broad, 0.2 times as long as article 3, bearing three aesthetascs and seven simple setae.

Antenna (Fig. 2e) article 1 naked. Article 21.4 times as long as broad, with one ventral and one dorsodistal setae. 
Article 3 about as long as broad, naked. Article 42.6 times as long as broad, with one ventrodistal, one dorsodistal and one subdistal setae. Article 52.7 times as long as broad, distal margin with two long, two short simple setae and two dorsal penicillate setae. Article 61.3 times as long as broad, with eleven simple setae.

Mouthparts. Labrum (Fig. 3a) rhomboidal, with setules. Left mandible (Fig. 3b) pars incisiva straight, with distal fine crenulation; lacinia mobilis broad, distally with five lobes, accesory seta denticulate; pars molaris with corrugated grinding surface. Right mandible (Fig. 3c) as left, but lacinia mobilis smaller and narrower, distally smooth. Labium (Fig. 3d) lobes with setules, palp present. Maxillule (Fig. 3e, f) with eight distal serrulate spines, dorsodistally with several thin setae; palp (Fig. 3f) with three distal and one subdistal setae. Maxilla (Fig. 3g) ovoid, simple. Maxilliped (Fig. 3h) coxa with two inner setae; basis 0.6 times as long as broad, with one shorter and one longer distal setae; palp article 1 with two outer setae, article 2 with one outer and five inner serrulate setae, article 3 with twelve inner serrulate setae, article 4 with eight inner distal and one outer subdistal serrulate setae. Maxilliped endites (Fig. 3i) each with denticulate, setose margins and two distal pappose seta. Epignath (Fig. 3j) linguiform, margins setulose, with distal setulose spine.

Cheliped (Fig. 4a) sclerite with two setae. Basis 1.4 times as long as broad, with ventrodistal seta. Merus with three ventral setae and tuft of three setae near carpus. Carpus 1.3 times as long as broad, with three ventral and three dorsodistal setae. Propodus 1.4 times as long as broad, with five ventral setae, two outer setae on palm, four setae on fixed finger near dactylus insertion, nine setae near cutting edge, cutting edge with proximal invagination. Dactylus as long as fixed finger, with slight ventral apophysis and ventral row of six setules.

Pereopod 1 (Fig. 4b) coxa with apophysis, bearing two setae. Ischio-basis 3.5 times as long as broad, dorsal margin with one simple and one penicillate setae. Merus 0.3 times as long as basis, with one ventrodistal seta. Carpus 1.2 times as long as merus, with one dorsodistal and one ventrodistal simple setae. Propodus 1.7 times as long as carpus, 4.7 times as long as broad, with one dorsal penicillate seta, one dorsodistal and four ventrodistal setae. Dactylus and unguis together 0.5 times as long as propodus, dactylus with one proximal seta, unguis 1.7 times as long as dactylus.

Pereopod 2 (Fig. 4c) coxa with anterior pair of setae. Ischio-basis 3.0 times as long as broad, with two dorsal penicillate setae and three ventrodistal simple setae. Merus 0.4 times as long as basis, dorsodistal margin with one simple seta, ventrodistal margin with one spine, two simple setae and microtrichia. Carpus 0.9 times as long as merus, with four distal compound spines, dorsodistal margin with two setae, ventrodistal corner with two setae and microtrichia. Propodus 1.5 times as long as carpus, 3.6 times as long as broad with two ventral simple setae, one dorsal penicillate seta and one dorsodistal simple seta. Dactylus and unguis together 0.5 times as long as propodus, unguis 1.9 times as long as dactylus.

Pereopod 3 (Fig. 4d) coxa with anterior pair of setae. Ischio-basis 3.0 times as long as broad, with one dorsal simple seta one dorsal penicillate seta, and tuft of three ventrodistal setae. Merus 0.4 times as long as basis, dorsodistal margin with one simple seta, ventrodistal margin with cuticular tubercles, one spine and two simple setae. Carpus 0.8 times as long as merus, with ventral cuticular tubercles and microtrichia, four distal compound spines, two dorsodistal and one ventrodistal setae. Propodus 1.3 times as long as carpus, with two ventral and one ventrodistal setae. Dactylus and unguis together 0.6 times as long as propodus. Unguis 1.6 times as long as dactylus.

Pereopod 4 (Fig. 4e) ischio-basis 3.0 times as long as broad, with one dorsal penicillate seta, two ventral penicillate seta, and three ventrodistal simple setae. Merus 0.5 times as long as basis, with ventral cuticular tubercles and microtrichia, ventrodistal margin with two spines and one seta, dorsodistal margin with one seta. Carpus 0.7 times as long as merus, with ventral cuticular tubercles and microtrichia, two subdistal setae and four distal compound spines. Propodus 1.3 times as long as carpus, with two ventral, one dorsal and one subdistal setae. Dactylus and unguis fused into a claw, curved, with ventral microtrichia and inner and outer lateral comb of six spinules.

Pereopod 5 (Fig. 4e) ischio-basis 3.0 times as long as broad, with one dorsal penicillate seta, three ventrodistal simple setae. Merus 0.5 times as long as basis, with ventral cuticular tubercles and microtrichia, ventrodistal margin with two spines and one seta, dorsodistal margin with one seta. Carpus 0.7 times as long as merus, with ventral cuticular tubercles, two subdistal setae and four distal compound spines. Propodus 1.3 times as long as carpus, with two ventral, one dorsal and two subdistal simple setae and one dorsal penicillate seta. Dactylus and unguis fused into a claw, curved, with ventral microtrichia and inner and outer lateral comb of seven spinules.

Pereopod 6 (Fig. 4f) ischio-basis 2.6 times as long as broad, with two dorsal penicillate setae and one ventrodistal simple seta. Merus 0.5 times as long as basis, ventrodistal margin with two spines and three setae. Carpus 0.9 times as long as merus, with ventral microtrichia, four distal spines and two dorsodistal setae. Propodus 1.3 times as long as carpus, with row of ten leaf like spines, three ventral setae, one penicillate and three simple dorsodistal setae. Dactylus and unguis fused into a claw, curved, with ventral microtrichia and inner and outer lateral combs of seven spinules. 
Pleopods 1 and 2 (Fig. 4g) basis with one inner and six outer plumose setae. Exopod outer edge with about 18 plumose setae. Endopod inner edge with one medial plumose seta, outer edge with about ten plumose setae, distalmost distinctively shorter and stouter than rest. Pleopod 3 basis with no inner and three outer plumose setae.

Uropods (Fig. 1c) of three segments plus basis. Basis 3.0 times as long as broad, with four setae. Segments all subequal in length, with four or five distal simple setae.

Juvenile specimens do not present significant differences with females, but for the absence of oostegites or marsupia.

\section{Description of male}

As female, but for the following characters:

Body (Fig. 5a) 4.0 times as long as broad. Cephalothorax subtriangular, as long as broad, eyes with visual elements present, lateral margins with one seta each. Pereonite 1 0.2 times as long as broad. Pereonite 21.3 times as long as pereonite 1 and 0.3 times as long as broad. Pereonite 3 as pereonite 2 . Pereonite 41.4 times as long as pereonite 3 and 0.5 times as long as broad. Pereonite 5 as pereonite 4 . Pereonite 60.4 times as long as pereonite 5 and 0.4 times as long as broad. Pleonite 10.3 times as long as broad, about as long as pereonite 6 . Pleonite 2 as pleonite 1. Pleonite 30.9 times as broad as pleonite 2. Pereonites 4 and 50.7 times as long as pleonite 3 .

Antennule (Fig. 5d) just longer as cephalothorax. Article 16.0 times as long as broad, with one medial seta, three simple and one penicillate dorsodistal setae and two simple, two penicillate subdistal setae. Article 20.4 times as long as article 1, with three dorsodistal simple setae, two subdistal setae, and two simple and two penicillate ventrodistal setae. Article 30.8 times as long as article 2, with one dorsodistal and one ventrodistal setae. Distal article shorter than long, with six setae and five aesthetascs.

Antenna (Fig. 5e) Article 1 as long as broad, naked. Article 22.7 times as long as broad, with one ventroproximal, one ventrodistal, one mediodorsal and one dorsodistal setae. Article 30.6 times as long as article 2, naked. Article 42.3 times as long as broad, with three dorsodistal and one ventrodistal setae. Article 50.6 times as long as article 4, with two penicillate and three simple setae, one shorter. Article 60.4 times as long as article 5, with eight distal setae.

Cheliped (Fig. 5b, c) basis about as long as broad, with ventrodistal seta. Merus ventral margin longer than that of carpus, with three ventral setae and two setae near insertion with basis. Carpus broad, ventral margin short, about as long as broad, with three ventral setae, three dorsodistal setae and three short setae along dorsal margin. Propodus twice as long as broad, ventral margin with four setae, cutting edge with proximal triangular apophysis and five setae; outer surface with row of three setae near apophysis, tuft of five setae near tip of fixed finger, and three setae on palm, inner side with one seta near dactylus insertion and one near cutting edge apophysis. Dactylus arcuate, with proximal ventral apophysis and ventral row of short setae on incisive margin.

\section{Etymology}

From the Spanish bulto (bump) and the Latin dactylus (finger, metonymy from the greek daktulos, that refers to the three last bones of the finger). In reference to the ventral apophyses on the cheliped dactylus.

\section{Remarks}

Hexapleomera bultidactyla sp. nov. is the only species of the genus having a ventral apophysis on cheliped dactylus. Otherwise, it is most similar to the sympatric species H. robusta as redescribed by Sieg [1] (see table 1 in [3]) in having five aesthetascs on the male antennule, a maxilliped basis with two setae and endite without spines, male cheliped dactylus with spinules, male and female chela fixed finger with apophysis, pleopod endopod with one inner seta, and uropod with four segments. Hexapleomera robusta sensu Sieg [2] is different from $H$. bultidactyla in having three setae near each eye, no dorsal setae on pereonites, eight aesthetascs on female antennule, eight setae on maxillule palp, male chela fixed finger with four setae, coxa 1 without apophysis, pleopods 1 and 2 basis with seven inner setae, and pleopod 3 basis with four outer setae.

Hexapleomera satella shares with $H$. bultidactyla the presence of three aesthetascs on the female antennule, four terminal setae on the maxillule palp, two setae on the maxilliped coxa, the presence of short setae on the male cheliped dactylus and the presence of an apophysis on the coxa of pereopod 1, and uropods of four segments. It differs on the presence of two setae near each eye, a pair of dorsal setae on the male cephalothorax, four aesthetascs on the antennule, chela fixed finger with three ventral setae only, absence of an apophysis on male chela fixed finger and five inner setae on basis of pleopods 1 and 2.

Hexapleomera edgari Bamber, 2012 from Australia differs from $H$. bultidactyla in having two setae near each eye, the male and female antennules with six aesthetascs, the maxillule palp with five setae, maxilliped coxa with three setae, maxilliped endite with spines, chela fixed finger with six ventral setae, the female having triangular apophysis, apophysis on coxa of pereopod 1 absent, pleopods 1 and 2 basis with five inner setae, and pleopod endopod with two inner setae.

Only the male of Hexapleomera moverleyi (Edgar, 2008), also from Australia, is known. It shares with the 
male of $H$. bultidactyla having only one seta near each eye, five aesthetascs on the antennule, two setae on the maxilliped coxa and presence of an apophysis on the coxa of the pereopod 1. It differs in having five setae on maxillule palp, one seta on the maxilliped basis, the maxilliped endite with spines, chela dactylus with no short setae, chela fixed finger with five ventral setae and no apophysis, pleopod 1 and 2 basis with five inner setae, pleopod 3 basis with one inner seta, and uropod of five segments.

Finally, Hexapleomera wombat Bamber, 2012 from the eastern Mediterranean has, like the new species, one seta near each eye, no spines on the maxilliped endite, and no proximal apophysis on the female chela fixed finger, but it is different in having six and four aesthetascs on the male and female antennules respectively, five setae on the maxillule palp, three setae on maxilliped coxa and one on basis, chela fixed finger with five setae, no apophysis on male chela fixed finger, absence of apophysis on coxa 1 , five inner setae on basis of pleopods 1 and 2, and uropod of five segments.

\section{Identification key to the species of Hexapleomera (modified after Bamber [4])}

1. Adult uropod five-segmented; maxilliped basis with one distal seta; maxillule palp with five distal setae....2 Adult uropod four-segmented; maxilliped basis with two distal setae...

2. Spinulation of male cheliped dactylus present; pereopod 1 coxa without apophysis.........H. wombat Bamber, 2012

Spinulation of male cheliped dactylus absent; pereopod 1 coxa with apophysis.........H. moverleyi (Edgar, 2008) [8]

3. Male chela without large apophysis on cutting edge of fixed finger; maxillule palp with four or five distal setae.. ....4 Male chela with large apophysis on cutting edge of fixed finger; maxillule palp with eight distal setae.......5

4. Pleopod endopod with two inner setae; maxillule palp with five distal setae; male chela without proximoventral apophysis on fixed finger; six aesthetascs on female antennules.........H. edgari Bamber, 2012 Pleopod endopod with one inner seta; maxillule palp with four distal setae; male chela with proximoventral apophysis on fixed finger; three aesthetascs on female antennules.........H. satella Bamber, 2012

5. Pereonites with dorsal setation; male and female chela with proximal apophysis on dactylus (more prominent on male); female chela without triangular apophysis on fixed finger; pereopod 1 coxa with apophysis..........H. bultidactyla sp. nov.
Pereonites with no dorsal setation; male and female chela without proximal apophysis on dactylus; female chela with triangular apophysis on fixed finger; pereopod 1 coxa without apophysis.........H. robusta (Moore, 1894)

\section{Biology and ecology}

A total of 785 specimens of $H$. bultidactyla, including males, brooding and non-brooding females and juveniles, were counted in this study (Table 1). Mean density was $2201.8 \pm 983.7$ ind $\mathrm{m}^{-2}$, equivalent to $1626.7 \pm 1078.6$ ind $100 \mathrm{~g}^{-1}$ of dry weight habitat. The overall male/ female ratio was 0.13 , with an average of $0.25 \pm 0.10$ per sampling site (having omitted those sites where one of the genders was absent). An $11.1 \%$ of the counted females were ovigerous. The average number of eggs per female was $20.8 \pm 1.3$ and the highest number of eggs carried by a single female was 46 .

Hexapleomera bultidactyla occurred in fouling communities dominated by the mussel M. galloprovincialis Lamarck, 1819, the hydroid P. disticha Goldfuss, 1820 and turfs formed by Ceramiaceae algae and the hydroid Aglaophenia sp. The largest populations were counted in algae-hydroids turfs, with a maximum density of $15,263.2$ ind $\mathrm{m}^{-2}$. The species occurred in six of the 14 off-coast aquaculture facilities (Fig. 1), mainly those located in the western Mediterranean Sea. H. robusta was present together with $\mathrm{H}$. bultidactyla in two of the samples from Alicante, one sample from Santa Pola (near Alicante) and one from Croatia (Tables 1, 2).

\section{Discussion}

\section{Ecology and distribution}

The current numbers and density of fish cages scattered along some of the Mediterranean coasts provide a significant amount of hard substrata in off-coast areas where they are naturally absent, boosting the dispersion of associated species [9]. Macroinvertebrate species associated with fish farms have been shown to assimilate the organic matter derived of uneaten feed pellets and fish faeces [10], and tanaidaceans may also take advantage of this new trophic resource. Specifically, tanaidaceans represent between 0.03 and $15.9 \%$ of the mobile epifauna associated with fish farms fouling in the Mediterranean Sea, being the third group in importance after amphipods and polychaetes [11]. Hexapleomera robusta, previously reported from turtles in the Mediterranean [12-15], has been also observed associated to fish farm fouling in this study. According to [15], H. robusta may be found associated to the algae Polysiphonia sp, which is also part of fish farms fouling [11]. It is feasible that $H$. bultidactyla will be found in other natural habitats containing similar 
algae or hydroids species than those found in fish farm fouling.

\section{Sex ratio and fecundity}

The male/female ratio in tanaidomorphs varies from scarcely biased, nearly 1.0 in the family Agathotanaidae [16] to strongly female biased, to 0.001 in Leptocheliidae [17, 18]; in Tanaididae, Rumbold et al. [19] found values ranging from 0.01 to 0.16 in Tanais dulongii (Audouin, 1826), thus significantly lower than the average per sample registered here $(0.25)$.

These are the first data presented on the fecundity of any Hexapleomera species. The values found in this study $(20.81 \pm 1.30$ embryos per female, with a maximum of 46 in a single female) are in agreement with other studies on the fecundity of the Tanaididae: for instance, Johnson \& Attranadal [20] recorded a maximum of 46 embryos in Tanais dulongii whereas Rumbold et al. [21] obtained averages of up to $39.1 \pm 15.3$ for the same species. Schmidt et al. [6] counted 19-31 in Allotanais hirsutus Beddard, 1886. Within the subfamily Pancolinae, the records come from species of Zeuxo Templeton1840: Masunari \& Sieg [22] measured an average of eleven embryos in Zeuxo coralensis Sieg, 1980, Bamber [23] counted 25 in Zeuxo holdichi Bamber, 1990, whereas he later counted 15 in Zeuxo zorro Bamber, 1997 [24]. Nakaoka [25] registered 20-40 embryos on the females of an undentified species of Zeuxo. Overall, our results lay within the general range for these records.

\section{Final considerations}

The relatively high densities documented here, and the presence of different developmental stages in the samples indicate that $H$. bultidactyla is represented by wellestablished populations in the fouling of the fish farms surveyed. As mentioned above, tanaidaceans have limited swimming capacity and no dispersive phase in the development; under these circumstances, the question of how this species has been able to colonize these isolated substrata with no contact with the seafloor arises. Limited swimming capacity has been described by Larsen [1], several species are known to cling on to floating objects [26], and species of Hexapleomera build tubes on large marine organisms such as manatees or sea turtles [ 4 and references therein]. Any of these dispersal mechanisms, or a combination of more than one, might explain the occurrence of large populations of $H$. bultidactyla on the fish farms fouling, but further experimental work would be needed to solve this question definitely.

\section{Abbreviations}

MNCN: Museo Nacional de Ciencias Naturales (Madrid); Prep. fem.: preparatory females; cop. females: copulatory females; juv: juvenles.

\section{Authors' contributions}

PE made microscopic observation, measurement, description and schemes of the tanaidacean specimens. VFG carried out the sampling work and revised, classified and counted the specimens. PE and VFG drafted the text. Both authors read and approved the final manuscript.

\section{Author details \\ ${ }^{1}$ Departamento de Biologia and CESAM, Universidade de Aveiro, Aveiro, Portugal. ${ }^{2}$ Departamento de Ciencias del Mar y Biología Aplicada, Universidad de Alicante, Alicante, Spain.}

\section{Acknowledgements}

We would like to thank the staff of the fish farms that gave us access and help for the study, and specially to CULMAR fish farms. We also thank Pablo Sanchez-Jerez and David Izquierdo-Gomez for their invaluable cooperation during the sampling work and to Joseph A. Borg (University of Malta), Tanja Segvic (Institute of Oceanography and Fisheries of Split, Croatia), Paolo Tomasseti (ISPRA, Italy), Felipe Aguado (IMIDA, Spain), Ignasi Gairin (IRTA, Spain) and Pablo Ávila (Junta de Andalucía, Spain) for kindly providing fouling samples. Comments from an anonymous referee contributed to improve this manuscript, and are greatly appreciated.

\section{Competing interests}

Both authors declare that they have no competing interests.

\section{Availability of data and materials}

The datasets during and/or analysed during the current study available from the corresponding author on reasonable request.

\section{Funding}

P. Esquete is supported by Fundacão para a Ciência e Tecnologia (FCT, Portugal), under postdoctoral Grant SFRH/BPD/94985/2013.

Received: 12 July 2016 Accepted: 15 November 2016

Published online: 23 December 2016

\section{References}

1. Larsen K. Deep-sea tanaidacea (Peracarida) from the Gulf of Mexico. Crustaceana. Monographs 5. Brill: Leiden; 2005.

2. Moore HF. Tanais robustus, a new species of Anisopoda. Proc Acad Nat Sci Phila. 1984;46:90-5.

3. Sieg J. Taxonomische Monographie der Tanaidae Dana, 1849 (Crustacea: Tanaidacea). Abh Senckb Naturforsch Ges. 1980;537:1-267.

4. Bamber RN. A re-assesment of Hexapleomera Dudich, 1931 (Crustacea: Tanaidacea:Tanaidae), with designation of three new species. Zootaxa. 2012:3583:51-70.

5. Masunari S. Postmarsupial development and population dynamics of Leptochelia savignyi (Krøyer, 1842) (Tanaidacea). Crustaceana. 1983;44:151-62.

6. Schmidt A, Siegel V, Brandt A. Postembryonic development of Apseudes heroae and Allotanais hirsutus (Tanaidacea, Crustacea) in Magellanic and sub-Antarctic waters. Antarct Sci. 2002;14:201-11.

7. Bamber RN, Sheader M. A reinterpretation of the taxonomy and zoogeography of Pakistanapseudes and Swireapseudes (Crustacea; Tanaidacea): Hong Kong taxa in the world context. In: Morton B, editor. Perspectives on marine environment Change in Hong Kong and Southern China, 1977-2001. Proceedings of an international workshop reunion conference, Hong Kong. Hong Kong: Hong Kong Univ. Press; 2003; p. 21-6.

8. Edgar GJ. Shallow water Tanaidae (Crustacea: Tanaidacea) of Australia. Zootaxa. 2008;1836:1-92. 
9. Fernandez-Gonzalez V, Sanchez-Jerez P. First occurrence of Caprella scaura Templeton, 1836 (Crustacea: Amphipoda) on off-coast fish farm cages in the Mediterranean Sea. Helgoland Mar Res. 2013;68(1):187-91.

10. Gonzalez-Silvera D, Izquierdo-Gomez D, Fernandez-Gonzalez V, MartínezLópez FJ, López-Jiménez JA, Sanchez-Jerez P. Mediterranean fouling communities assimilate the organic matter derived from coastal fish farms as a new trophic resource. Mar Pollut Bull. 2015;91(1):45-53.

11. Fernandez-Gonzalez V, Sanchez-Jerez P. Fouling assemblages associated with off-coast aquaculture facilities: an overall assessment of the Mediterranean sea. Mediterr Mar Sci. doi:10.12681/mms.1806.

12. Sanz MC. Contribución al conocimiento de los Crustáceos litorales del Mediterráneo occidental (tanaidáceos). Ph.D. thesis, Universidad Autónoma de Barcelona. 1993; 668 p.

13. Bentivegna F, Cirino P, Toscano A. Care and treatment of loggerhead sea turtles from the Gulf of Naples, Italy. Mar Turt Newslett. 1993;61:6-7.

14. Kitsos MS, Christodoulou M, Arvanitidis C, Mavidis M, Kirmitzoglou I, Koukouras A. Composition of the organismic assemblage associated with Caretta caretta. J Mar Biol Assoc UK. 2005;85(02):257-61.

15. Domènech F, Badillo FJ, Tomás J, Raga JA, Aznar FJ. Epibiont communities of loggerhead marine turtles (Caretta caretta) in the western Mediterranean: influence of geographic and ecological factors. J Mar Biol Assoc UK. 2005:95(04):851-61.

16. Bird GJ. Tanaidacea (Crustacea, Peracarida) of the North-east Atlantic: the Agathotanaidae of the AFEN, BIOFAR and BIOICE projects, with a description of a new species of Paragathotanais Lang. Zootaxa. 2010;22:1-22.

17. Bamber RN. In the footsteps of Henrik Nikolaj Krøyer: the rediscovery and redescription of Leptochelia savignyi (Krøyer, 1842) sensu stricto (Crustacea:Tanaidacea: Leptocheliidae). P Biol Soc Wash. 2010;123:289-311.
18. Ishimaru S. A new species of Leptochelia (Crustacea, Tanaidacea) from Japan, with a redescription of L. savignyi (Kroyer, 1842). Pub Seto Mar Biol Lab. 1985;30:241-67.

19. Rumbold CE, Obenat SM, Spivak ED. Life history of Tanais dulongii (Tanaidacea: Tanaidae) in an intertidal flat in the southwestern Atlantic. J Crustacean Biol. 2012;32:891-8.

20. Johnson S, Attranadal YG. Reproductive behaviour and larval development of Tanais cavolirrii (Crustacea: Tanaidacea). Mar Biol. 1982;71:11-6.

21. Rumbold CE, Obenat SM, Spivak ED. Comparison of life history traits of Tanais dulongii (Tanaidacea: Tanaididae) in natural and artificial marine environments of the south-western Atlantic. Helgol Mar Res. 2015;69:231-42.

22. Masunari S, Sieg J. Morphological and ecological notes on Zeuxo coralensis- Sieg, 1980 from Brazil. Stud Neotrop Fauna Environ. 1980;15:1-8.

23. Bamber RN. A new species of Zeuxo (Crustacea: Tanaidacea) from the French Atlantic coast. J Nat Hist. 1990;24:1587-96.

24. Bamber RN, Bird G. Peracarid Crustaceans from Cape D'Aguilar and Hong Kong, III. Tanaidacea:Tanaidomorpha, Hong Kong. In: Morton B, editor. The marine Fauna anf Flora of Hong Kong and Souhern China IV. Hong Kong: Hong Kong University Press; 1997. p. 103-42.

25. Nakaoka M. Predation on seeds of seagrasses Zostera marina and Zostera caulescens by a tanaid crustacean Zeuxo sp. Aquat Bot. 2002;72:99-106.

26. Highsmith RC. Floating and algal rafting as potential dispersal mechanisms in brooding invertebrates. Mar Ecol Prog Ser. 1985;25(2):169-79.

\section{Submit your next manuscript to BioMed Central and we will help you at every step:}

- We accept pre-submission inquiries

- Our selector tool helps you to find the most relevant journal

- We provide round the clock customer support

- Convenient online submission

- Thorough peer review

- Inclusion in PubMed and all major indexing services

- Maximum visibility for your research

Submit your manuscript at www.biomedcentral.com/submit 